\title{
A call to action from the lab bench
}

Basic researchers in Britain and elsewhere must become more informed about science policy and more active as campaigners if their profession is to survive. Useful lessons can be learned from colleagues in the United States.

\section{Michelle Peckham}

It is remarkable that so many working scientists, at least in the United Kingdom, take so little interest in science policy, even though it affects them directly. When I recently presented a poster on the subject at a meeting of Royal Society university research fellows, only 20 per cent of those handed a questionnaire about science policy issues responded. A survey into potential difficulties in obtaining research funding conducted by the Royal Society generated a similar response.

It is true that many scientists are aware of the 1993 government white paper 'Realising Our Potential', an influential statement on science policy. But few have read either the paper itself or the Technology Foresight reports for their areas of research which arose from it.

One frequent complaint is that scientists need to concentrate on their research and teaching, and do not have enough time to follow broader science policy debates. A few do follow such debates, but most ignore them. Many others feel that, as individuals, they are unable to influence policy, and therefore choose not to object publicly to decisions they disagree with.

Why should scientists be aware of recent changes in science policy? The main reason is that grants for basic research are hard to obtain these days, not only because of cuts in government spending, but also because funds are being redirected from scientist-led, basic research towards strategic goals.

\section{Industry's interests}

Less money is available for responsive-mode basic research, which most academics use to obtain research funding because research councils are forced to redirect money into initiatives such as Technology Foresight, and the ROPA (Realise Our Potential Awards) scheme arising from the white paper. Ian Lang, the President of the Board of Trade, recently

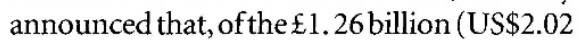
billion) research budget for 1996-97, £778 million (equivalent to 73 per cent of the research councils' budget) will be invested in programmes related to Technology Foresight. This has apparently been welcomed by much

Table 1 Web sites containing policy information
Office of Science and Technology (OST)
Parliamentary Office of Science and Technology
Higher. Education Funding Council for England
Research councils
Royal Society
Save British Science

of industry, as it identifies long-term research priorities. But are academic researchers prepared to accept that their research agenda is dictated by industry?

The ROPA scheme rewards researchers who have already collaborated successfully with industry, as researchers are only eligible to apply if they have previously won $£ 25,000$ of industry funding. But not only does it use money that could have been used for peer reviewed research grants, it also results in funding research that might well not have been funded that way. ROPA proposals are not peer reviewed, but decided by a committee, many members of which will not be expert in the area of the research proposals.

On top of this, basic research in British universities is also threatened by cuts in the money that universities receive through the higher education funding councils. Each university now receives support for research based on its score in the national Research Assessment Exercise conducted every three to four years (the most recent was completed in January). It also receives money via the capital equipment budget, allocated by the Higher Education Funding Council for England (HEFCE) largely on student numbers.

In 1995, the government cut funds for capital expenditure by a staggering 35 per cent, wrongly assuming that this could be made up from private finance initiatives. Partly as a result of the threat by vice-chancellors to introduce fees for students, hitherto taught free, and industry's refusal to pay up, the government has acknowledged its mistake, not implemented further threatened cuts and has partly made up the 35 per cent deficit.

The picture is certainly gloomy. If scientists do not start taking notice of recent changes in the way that science is run, it will be hard to resist the threat to basic research. Scientists must not only inform themselves about science policy, but actively lobby parliament for the science policies they want. In the United States, the Federation of American Societies for Experimental Biology (FASEB) employs a lobbyist to represent its interests to Congress. The goal is to promote biological research to government and the public.

Members of FASEB's constituent bodies

http://wwww.open.gov.uk/ost/science.htm http://www.open.gov.uk/osthome.htm http://www.parliament.uk/post/home.htm http://www.hefce.ac.uk/ http://www.nerc.ac.uk/joint_res councils.htmi

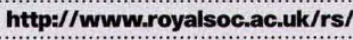
http://dspace.dial.pipex.com/sbs/ are asked to lobby their congressional representatives by e-mail, and newsletters keep them up to date about relevant issues, and suggest appropriate action. The recent 6.7 per cent increase of the US science budget appears to have been partly the result of such concerted, direct action by scientists.

In the United Kingdom, the number of individuals who are concerned with influencing science policy is much smaller. Many professional societies, including the Royal Society of Chemistry, Institute of Physics, Institute of Biology and the Royal Society, actively lobby parliament. But, although many smaller societies are affiliated to these larger groups, science policy issues are rarely reported on in their newsletters. So most scientists are neither informed about such issues, nor encouraged by their professional societies to become involved in them.

\section{The need for lobbying}

One independent body openly critical of government science policy is Save British Science (SBS). It was set up just over 10 years ago by a small group of researchers in reaction to cuts in research funding. SBS informs its members about policy issues, asks them to voice their opinions to the media, and has written a comprehensive document setting out how science should be funded. But its membership remains low at just 4,000 , and most of its lobbying is done by its central committee.

Yet it is vitally important that more scientists become actively involved in sciencepolicy. Scientific societies could coordinate lobbying of MPs, ministers and policy coordinators by individual scientists. These societies could also start to inform members about science policy, by reports in newsletters, and e-mails. However, an organization similar to FASEB is unlikely to work so well in the United Kingdom, as politicians tend to dismiss much of the activities of lobby groups as 'special interest groups'. It is also up to scientists themselves to devote at least some of their limited free time to keeping up to date on policy, for example by reading reports in magazines, and consulting information posts on the Internet sites(see Table 1).

It is vital that more, and younger, academic scientists start to become involved in policy debates, and attempt to persuade politicians to defend their interests. At best, it would improve science funding in Britain; at worst, it could be the only way that basic research in the UK - and elsewhere - will survive.

Michelle Peckman is at the Randall Institute, King's College, London, 26-29 Drury Lane, London WC2B 5RL, UK. 